\title{
ANALISIS KLT BIOAUTOGRAFI EKSTRAK KULIT BATANG TANAMAN KAYU JAWA (Lannea coromandelica) TERHADAP BAKTERI Staphylococcus aureus DAN Shigella dysentriae
}

[TLC Bioautography Analysis of Extract Javanese Wood Stem Bark (Lannea
coromandelica) to Staphylococcus aureus and Shigella dysentriae Bacteria]

\author{
Yumita $^{1}$, Abd. Rahman Razak ${ }^{1^{*}}$, Indriani ${ }^{1}$, Syaiful Bahri ${ }^{1}$ \\ 1) Jurusan Kimia, Fakultas MIPA, Universitas Tadulako, Palu \\ J. Soekarno Hatta Km.9, Kampus Bumi Tadulako Tondo Palu, Telp. 0451- 422611
}

*)Coresponding author: arrazak@gmail.com

Diterima 2 Mei 2019, Disetujui 22 Juni 2019

\begin{abstract}
Java wood plants (Lannea coromandelica) is a traditional medicinal plant which is still often used by people to treat internal and external wounds. The study aims to determine the effect of solvent polarity in Javanese stem bark extract on Staphylococcus aureus and Shigella dysenteriae, and to identify the compound groups which had an antibacterial activity against Staphylococcus aureus and Shigella dysenteriae with KLT-Bioautography analysis. The results show that the $\mathrm{n}$-hexane extract of Javanese bark is not showing an antibacterial activity against Staphylococcus aureus and Shigella dysenteriae, whereas the ethyl acetate extract and methanol of Javanese bark show an antibacterial activity against Staphylococcus aureus and Shigella dysenteriae. The results of the TLCBioautography test show negative results for Staphylococcus aureus and Shigella dysenteriae.
\end{abstract}

Keywords: Lannea coromandelica, antibacterial, Staphylococcus aureus, Shigella dysentriae, KLTBioautografi

\begin{abstract}
ABSTRAK
Tanaman kayu jawa (Lannea coromandelica) merupakan salah satu tanaman obat tradisional yang masih sering digunakan masyarakat untuk mengobati luka dalam maupun luar. Tujuan penelitian ini untuk mengetahui pengaruh kepolaran pelarut ekstrak kulit batang kayu jawa terhadap Staphylococcus aureus dan Shigella dysenteriae dan mengetahui golongan senyawa apa saja yang mempunyai aktivitas antibakteri terhadap Staphylococcus aureus dan Shigella dysenteriae dengan analisis KLT-Bioautografi. Hasil penelitian menunjukan bahwa ekstrak n-heksan kulit batang kayu jawa yang tidak mempunyai aktivitas antibakteri terhadap Staphylococcus aureus dan Shigella dysenteriae sedangkan ekstrak etil asetat dan metanol kulit batang kayu jawa mempunyai aktivitas antibakteri terhadap Staphylococcus aureus dan Shigella dysenteriae. Hasil uji KLT-Bioautografi tidak menunjukan hasil yang positif terhadap Staphylococcus aureus dan Shigella dysenteriae.
\end{abstract}

Kata kunci: Lannea coromandelica, antibakteri, Staphylococcus aureus, Shigella dysentriae, KLTBioautografi. 


\section{LATAR BELAKANG}

Tanaman kayu jawa (Lannea coromandelica) merupakan salah satu tanaman obat tradisional yang masih sering digunakan masyarakat karena memiliki berbagai khasiat antara lain digunakan untuk mengobati luka dalam maupun luar seperti diare, mual dan muntah (Rahayu et al., 2006). Berdasarkan skrining fitokimia, kulit batang tanaman kayu jawa (Lannea coromandelica) dilaporkan mengandung senyawa golongan karbohidrat, steroid, alkaloid, terpenoid, saponin, tannin, dan flavonoid (Manik et al., 2013).

Beberapa pengujian pada tanaman ini di sudah dilakukan salah satunya uji antibakteri menggunakan ekstrak etanol. Hasil uji aktivitas antibakteri yang dilakukan yaitu bakteri Staphylococcus aureus menunjukan aktivitas pada konsentrasi 500 ppm dengan diameter zona hambat $7.1 \mathrm{~mm}$. Bakteri Escherichia coli menunjukan aktivitas pada konsentrasi 500 ppm, 250 ppm dan 125 ppm dengan diameter zona hambat berturut-turut $8.5 \mathrm{~mm}, 7.8 \mathrm{~mm}$, dan 7.0 mm. Bakteri Helicobacter pylori menunjukan aktivitas pada konsentrasi 500 ppm dan 250 ppm dengan diameter zona hambat $8.2 \mathrm{~mm}$ dan $7.3 \mathrm{~mm}$. Bakteri Pseudomonas aeruginosa menunjukan aktivatas pada konsentrasi 500 ppm dan 250 ppm dengan diameter zona hambat $8.5 \mathrm{~mm}$ dan $6.8 \mathrm{~mm}$ (Rahmadani, 2015). Berdasarkan hasil penelitian sebelumnya bahwa, fraksi n-heksan, diklorometana, dan etil asetat kulit batang dan daun tanaman kayu jawa memiliki aktivitas antimikroba dan trombolitik (Manik et al., 2013), selain itu ekstrak metanol kulit batang kayu jawa memiliki aktivitas antidiare yang disebabkan mikroorganisme patogen (Rajib et al., 2013).

Meskipun beberapa penelitian telah melaporkan golongan senyawa dalam kayu, namun demikian belum diketahui bagaimana distribusi dan prospektifitas senyawa yang terdapat dalam kulit batang kayu jawa. Oleh karena itu diperlukan pengujian yang menghasilkan data lebih akurat melalui analisis KLT-Bioautografi ekstrak kulit batang tanaman kayu jawa (Lannea coromandelica) terhadap bakteri Staphylococcus aureus dan Shigella dysenteriae.

\section{METODE PENELITIAN}

\section{Bahan dan Peralatan}

Bahan yang digunakan adalah kulit kayu jawa, n-heksan, etil asetat, metanol, klorofrom, aquadest, Nacl fisologis, media Natrium agar (NA), spiritus, DMSO, kloromfenikol, pereaksi penyemprot, aluminium foil, plat KLT, kertas saring dan tissu.

Alat-alat yang digunakan meliputi neraca analitik, lumpang, alu, ayakan 60 mesh, corong Buchner, vacuum rotary evaporator, jangka sorong, botol semprot, sendok zat, pipet tetes, oven, autoklaf (Hirayama), incubator (POL-EKO Aparatura), ose, lampu bunsen, 
seperangkat alat $\mathrm{KLT}$, lampu $\mathrm{UV}_{254} \mathrm{~nm}$ dan $\mathrm{UV}_{366} \mathrm{~nm}$, Laminar Air Flow (Esco Class II BSC).

\section{Prosedur Penelitian}

\section{Ekstraksi}

Kulit batang kayu jawa dikeringkan, dipotong-potong kecil dan dihaluskan. Kemudian diayak dengan ayakan 60 mesh untuk memperoleh serbuk kulit kayu jawa. Serbuk kulit kayu jawa sebanyak 100 gram direndam dalam pelarut $\mathrm{N}$-heksan sebanyak $1000 \mathrm{~mL}$ selama 3 × 24 jam sesekali diaduk. Selanjutnya ekstrak yang diperoleh disaring menggunakan corong Buchner dan diuapkan pelarutnya menggunakan vacuum rotary evaporator sampai diperoleh ekstrak kental. Perlakuan yang sama juga dilakukan pada pelarut etil asetat dan metanol.

\section{Pengujian Aktivitas Antibakteri dengan Metode Sumur Difusi (Darmawati, 2009)}

Alat-alat kaca yang digunakan dicuci bersih dan dibungkus kertas dimasukkan dalam oven pada suhu $175^{\circ} \mathrm{C}$ selama 90-120 menit (pemanasan kering). Alat yang telah disterilkan dapat langsung dipakai atau disimpan dalam keadaan tertutup rapat. Pengujian aktivitas antibakteri dilakukan dengan menggunakan metode difusi sumur. Media Nutrien Agar (NA) sebanyak $25 \mathrm{ml}$ dicampurkan dengan $500 \mu \mathrm{L}$ suspense bakteri uji sesuai perlakuan (Staphylococcus aureus dan Shigella dysenteriae), kemudian dihomogenkan lalu dituang kedalam cawan petri steril dan dibiarkan sampai memadat. Selanjutnya dibuat 3 sumur yang berdiamater $\pm 6 \mathrm{~mm}$ menggunakan alat pelubang. Pada masing-masing lubang/sumur diisi dengan control negatif , control positif berupa kloromfenikol, ekstrak n-heksan, ekstrak etil asetat dan ekstrak metanol, setiap sumur diisi ekstrak dan control sebanyak $100 \mu \mathrm{L}$. Kemudian diingkubasi selama 24 jam pada suhu $37^{\circ} \mathrm{C}$.

\section{Pengujian KLT-Bioautografi (Rozalia, 2013).}

Uji KLT bioautografi dilakukan untuk mendeteksi senyawa aktif yang mempunyai aktifitas sebagai antibakteri. Pada plat KLT ditotolkan ekstrak nheksan, ekstrak etil asetat dan ekstrak methanol. Kemudian dielusi dalam bejana dengan fase gerak berbagai sistem campuran eluen. Setelah itu Plat KLT hasil delusi ditempelkan pada media NA (Natrium agar) yang telah diinokulasi dengan $1000 \mu \mathrm{l}$ bakteri. Kemudian plat KLT didiamkan selama 30 menit, lalu plat KLT diangkat. Setelah itu amati jika ada bercak pada kromatogram yang ditandai dengan adanya zona jernih yang tidak ditumbuhi mikroba. selanjutnya noda yang membentuk zona hambat pada lempeng KLT disemprot dengan pereaksi semprot untuk menentukan jenis senyawa yang menghambat. 
HASIL DAN PEMBAHASAN

Hasil Ekstraksi

Hasil ekstrak pekat yang diperoleh pada simplisa kayu jawa untuk ekstrak N-heksan sebanyak 1,20 gram, ekstrak etil asetat sebanyak 4,87 gram, dan ekstrak metanol sebanyak 27,57 gram. Rendeman yang diperoleh untuk ekstrak n-heksan sebanyak $1,20 \%$, etil asetat sebanyak $4,87 \%$, dan metanol sebanyak $27,57 \%$.

\section{Hasil Uji Aktivitas Antibakteri}

Uji ekstrak N-heksan, etil asetat, dan metanol kulit batang kayu jawa terhadap Staphylococcus aureus dan Shigella dysentriae dilakukan dengan difusi agar.

Tabel 1. Hasil diameter zona hambat ekstrak n-heksan, etil asetat, dan metanol

\begin{tabular}{ccccccc}
\hline \multirow{2}{*}{ Ulangan } & \multicolumn{6}{c}{ Diameter zona hambat (mm) } \\
\cline { 2 - 7 } & \multicolumn{3}{c}{ Staphylococcus aureus } & \multicolumn{3}{c}{ Shigella dysentriae } \\
\cline { 2 - 7 } & n-heksan & Etil asetat & Metanol & n-heksan & Etil asetat & Metanol \\
\hline I & 0 & 12.25 & 9.03 & 0 & 12.25 & 9.03 \\
\hline II & 0 & 12.75 & 12.13 & 0 & 10.15 & 10.35 \\
\hline III & 0 & 14.33 & 12.85 & 0 & 11.75 & 11.03 \\
\hline Rata-rata & 0 & 13.11 & 11.34 & 0 & 11.38 & 10.14 \\
\hline
\end{tabular}

Berdasarkan hasil penelitian diatas dapat diketahui bahwa ekstrak n-heksan tidak memiliki aktivitas antibakteri hal ini ditandai dengan tidak adanya zona bening pada ekstrak tersebut. Ekstrak etil asetat dan ekstrak metanol kulit batang kayu jawa (Lannea coromandelica) memiliki aktivitas antibakteri terhadap bakteri Staphylococcus aureus dan Shigella dysentriae yang ditandai dengan adanya zona bening. Hal ini sesuai dengan Parekh et al. (2005) yang menemukan bahwa, aktivitas antibakteri dipengaruhi oleh polaritas senyawa yang diekstraksi oleh masing-masing pelarut.

Menurut Davis dan Stout (1971), berdasarkan zona bening yang terbentuk daya hambat dikelompokkan menjadi 4 kelompok yaitu sangat kuat bila zona hambat $>20 \mathrm{~mm}$, kuat $10-20 \mathrm{~mm}$, sedang 5-10 mm dan lemah $<5 \mathrm{~mm}$. Berdasarkan literatur diatas maka senyawa antibakteri dalam ekstrak etil asetat dan metanol termasuk kelompok antibakteri dengan daya hambat kuat terhadap kedua bakteri uji.

\section{Hasil Uji Kromatografi Lapis Tipis (KLT)}

Pemisahan senyawa ekstrak etil asetat kulit batang kkayu jawa (Lannea coromandelica) secara KLT menggunakan campuran eluen n-heksan : etil asetat (7:3), dan pemisahan senyawa ekstrak metanol kulit batang kkayu jawa (Lannea coromandelica) secara KLT menggunakan campuran eluen klorofrom : 
metanol (8:2) dari hasil penotolan kemudian dilihat bercaknya dengan menggunakan lampu $U_{254} \mathrm{~nm}$, lampu $U_{366 \mathrm{~nm}}$, penampak bercak $\mathrm{FeCl}_{3}, \mathrm{H}_{2} \mathrm{SO}_{4}$ dan Dragendroff.

Pada penyemprotan ekstrak etil asetat dengan $\mathrm{H}_{2} \mathrm{SO}_{4} 10 \%$ noda pada nomor 2 memberikan warna orange hal ini menunjukan adanya senyawa saponin Kemudian dilakukan penyemprotan ekstrak etil asetat dengan $\mathrm{FeCl}_{3}$ noda nomor 5 dan 6 memberikan warna hitam hal ini menunjukan adanya kandungan flavonoid hal ini sesuai dengan Nugrahaningtyas (2005) yang menyatakan bila senyawa flavonoid direaksikan dengan pereaksi $\mathrm{FeCl}_{3}$ akan menghasilkan warna hitam/abu-abu. Selanjutnya penyemprotan ekstrak etil asetat dengan dragendroff noda pada nomor 1 memberikan warna coklat. menandakan adanya kandungan golongan senyawa alkaloid hal ini sesuai dengan Wagner (1996) yang menyatakan bahwa senyawa alkaloid setelah direaksikan dengan dragendrof akan berwarna coklat pada sinar tampak.

Penyemprotan ekstrak metanol dengan $\mathrm{H}_{2} \mathrm{SO}_{4} 10 \%$ dan dragendroff tidak memberikan warna sama sekali dan penyemprotan ekstrak metanol kulit batang kayu jawa (Lannea coromandelica) yang disemprot dengan $\mathrm{FeCl}_{3}$ menberikan warna hitam hal ini menandakan adanya kandungan senyawa tanin, hal ini sesuai dengan penelitian lainnya dimana senyawa tanin akan memberikan warna hitam apabila disemprotkan dengan $\mathrm{FeCl}_{3}$ (Banu dan Nagarajan, 2014).

\section{Hasil Uji KLT-Bioautografi}

Bioautografi adalah suatu metode pendektesian untuk menemukan suatu senyawa antimikroba yang belum teridentifikasi dengan cara melokalisir aktivitas antimikroba tersebut pada suatu kromatogram hasil kromatografi lapis tipis (KLT).

Hasil KLT-Bioautografi ekstrak etil asetat dan ekstrak metanol kulit batang kayu jawa tidak memberikan hasil yang positif, hal ini disebabkan karena ekstrak pada lempeng kromatogram yang terlalu sedikit (konsentrasi senyawa yang sedikit) sehingga senyawa aktif dalam ekstrak tidak cukup kuat untuk menghasilkan hambatan.

\section{KESIMPULAN}

Ekstrak etil asetat dan metanol kulit batang kayu jawa (Lannea coromandelica) dengan konsentrasi 4\% menghasilkan aktivitas terhadap bakteri Staphylococcus aureus dengan diameter zona hambat rata-rata yaitu $13,11 \mathrm{~mm}$ dan $11,34 \mathrm{~mm}$ dan bakteri Shigella dysentriae dengan diameter zona hambat rata-rata yaitu 11,38 $\mathrm{mm}$ dan 10,14 $\mathrm{mm}$, sedengkan ekstrak n-heksan kulit batang kayu jawa dengan konsentrasi $4 \%$ tidak mempunyai aktivitas antibakteri. Hasil KLT-Bioautografi ekstrak etil asetat dan ekstrak metanol kulit batang kayu jawa tidak memberikan hasil yang positif 
sehingga perlu dilakukan penelitian lanjutan.

\section{DAFTAR PUSTAKA}

Banu, R. H., Nagarajan, N. 2014. TLC and HPTLC fingerprinting of leaf extracts of Wedelia chinensis (Osbeck) Merrill). Journal of Pharmacognosy and Phytochemistry, 2(6): 29-33.

Darmawati, S. 2009. Keanekaragaman Genetik Salmonella Typhi. Jurnal Kesehatan, 2(1) : 28 - 32.

Davis dan Stout. 1971. Disc plate method of microbiological antibiotic essay. Journal Of Microbiology 22(4).

Manik, M.A. Wahid, S.M.A. Islam, A. Pal, K.T. Ahmad. 2013. A Comparative Study of the Antioxidant, Antimicrobial and Thrombolytic Activity of the Bark and Leaves of Lannea coromandelica (Anacardiaceae). International Journal of Pharamaceutical Sciences and Research, 4(7):26092614.

Nugrahaningtyas, K, D., Sabirin, M., Tutik, D, W., 2005, Isolasi dan Identifikasi Senyawa Flavonoid dalam Rimpang Temu Ireng (Curcuma aeruginosa Roxb.) Biofarmasi, 3 (1): 32-38.

Parekh, J., Darshana, T., Jadeja, R. and Sumitra, C. 2005. Efficacy of Aqueous and Methanol Extracts of Some Medicinal Plants for Potential Antibacterial Activity. Turk J Biol, 29: 203-210.

Rahayu, Sunarti, S. Diah, P. Suhardjono. 2006. Pemanfaatan Tumbuhan Obat Secara Tradisional oleh Masyarakat Lokal di Pulau Wawonii, Sulawesi Tenggara. Jurnal Biodiversitas, 7(3).
Rahmadani, F. 2015. Uji Aktivitas Antibakteri dari Ekstrak Etanol 96\% Kulit Batang Kayu Jawa (Lannea coromandelica) Terhadap Bakteri Staphylococcus aureus, Escherichia coli, Helicobacter pylori, Pseudomonas aeruginosa. Skripsi. Jakarta: Fakultas Kedokteran dan IImu Kesehatan.

Rajib Majumder, Md. Safkath Ibne Jami, Md. Efte Kharul Alam and Md. Badrul Alam. 2013. Antidiarrheal Activity of Lannea coromandelica Linn. Bark Extract. AmericanEurasian Journal of Scientific Research, 8(3):128-134.

Rozalia, Maria. 2013. Aktivitas Antibakteri dan Bioautografi Ekstrak Etanol Kulit Kayu Akway (Drymis piperita Hook. F.) Terhadap Staphylococcus epidermis dan Salmonella thypi. Skripsi. Surakarta: Universitas Muhammadiyah Surakarta. 